\title{
PROMISES, MISTAKE, AND RECIPROCITY
}

\author{
Matcolm Sharp*
}

I

I

T IS A SOURCE OF SATISFACTION to be given some credit for stimulating the study of contractors' bidding practices made by Professor Schultz. The study is an excellent example of what can be done with modest resources and an indication of how much could be done with greater means.

It is true that the investigation made by Mr. Schultz does not lead to simple and indisputable conclusions. It is a study partly of practices, and here it meets the test of care and accuracy. It involves also an examination of attitudes or judgments. Here, however much the judgments of members of a trade may need careful attention by courts, it is always possible that in some respects their judgments represent limited or biased points of view which must be discounted. There is not much indication that the judgments reported here need correction for such reasons; though Mr. Schultz gives us an appropriate warming about the interests of owners which might benefit from unlimited shopping around among bidders by contractors.

Another difficulty with objective studies of commercial practices appears in Mr. Schultz's paper in interesting form. It would probably not be entirely clear to a layman why the tabulation of responses leads to the conclusions stated at the end of the paper. There is, so it seems, a suffcient body of opinion supporting the view that a bid ought not to be withdrawn on account of a rise in prices, at least if the contractor to whom it has been submitted will be worse off than he would have been had the bid not been submitted at all. The opinions reported seem, indeed, to go further, and to indicate a judgment on the part of both bidders and contractors that a bid ought not to be withdrawn under any circumstances because of a rise in prices, at least if the contractor has in turn made his bid. So far as appears, it may be a general respect for this judgment, and practice in conformity with it, which makes contractors somewhat unconcerned about the problem of the cases which have puzzled lawyers and courts. Nevertheless, the author concludes that his study tends to

* Professor of Law, University of Chicago Law School. 
results unfavorable to the judgment that a firm offer should, under some circumstances at least, be enforceable without regard to its acceptance.

The principal bases of the author's conclusion seem to be the responses which indicate an opinion that a bidder is not bound, by trade standards, unless the contractor is under obligation to him; and those which indicate that a contractor to whom a bid has been submitted is not himself bound, by trade standards, to award the job to any bidder until the contractor has accepted a bid. There seems to be considerable opinion the other way, especially on the first point. On the second point, a number of responses treat the contractor as bound to accept the bid which he has used in making his bid, perhaps on grounds somewhat analagous to those which explain the obligations arising out of the conduct of an auction "without reserve." There is an interesting difference of opinion about the obligations of the contractor; but we may accept for purposes of argument the author's conclusion that the favorable opinion does not seem general enough to support a recognition of the contractor's obligation before acceptance, if the question were presented, with our present knowledge, to a court.

It is however quite a different question whether the bidder who has submitted his bid to the contractor may be bound although the contractor is not. The author's conclusion that opinion does not support the view that the bidder is or should be bound depends in the end primarily on the opinion that the contractor is not or should not himself be bound. But the conclusion does not by any means follow from the premise.

It must be said that eminent students of the common law would apparently accept the argument made by Mr. Schultz and supported by some of his responses. Mr. Llewellyn in one of his articles uses a similar argument in dealing with a problem arising out of time intervals in correspondence. $\mathrm{He}$ is nevertheless a draftsman of the firm offer article of the Uniform Commercial Code, which the present study leads Mr. Schultz to question.

Dealing with the civil-law rule which permits an offeree effectively to reject by a letter dispatched later, but received by the offeror earlier, than a letter of acceptance, Mr. Llewellyn seems to rest his criticism of that rule principally on the following ground: "To fail to close the deal as against the offeree until the letter of agreement arrives is to extend [an] unbalanced risk of the market without observable reason." ' When the

I Our Case Law of Contract, Offer and Acceptance, II, 48 Yale L.J. 779, 795 n. 23 (I939). See also I Corbin, Contracts $\S \S 78,80$ (I950). The discussion of various matters in the present comment is illustrated more fully in Kessler and Sharp, Cases on Contract (Mimeographed, rev. ed., r95r) which is to be regularly published during the year. 
Court of Claims recently permitted an offeree thus effectively to anticipate the arrival of his letter of acceptance, ${ }^{2}$ a variety of opinions were expressed in the law reviews. ${ }^{3}$ It was indeed curious to observe how the decision of such a narrow question occasioned comments reflecting manners of thought so characteristic of the different schools. The comment of our review, ${ }^{4}$ though the board does not by any means always follow the faculty, ${ }^{5}$ reflected in this instance an opinion favorable to the result of the case, which has long been held by the author of the present comment.

Mr. Llewellyn would presumably disagree. Is his position on this point consistent with his draft of the firm offer section of the commercial code? It is hard for the reviewer to reconcile the positions, at least if the argument proceeds from the treacherous but familiar use of analogy to an examination of the unfamiliar but real premises of decisions, the premises of policy.

For if one asks why it should be a fatal objection to an obligation on the part of an offeror, to say that the offeree is not bound, he will in the end find himself facing policy questions. An offeror has, on the assumptions with which we must approach the problem, made a promise. In our troublesome case the promise further implies in fact an undertaking that it shall be unrevoked for some reasonable period. In the case of the subcontractor's bid, the implication that the offer shall remain unrevoked for a reasonable time appears in the opinions of bidders and contractors alike that it is not fair for the bidder to withdraw, at least after the contractor himself has bid, until the contractor has had a reasonable time to close with the bidder. In the case of the contract by correspondence, the rule that the offer is irrevocable after the dispatch of the letter of acceptance must depend, so far as it is rational at all, on the view that the offer contains not only a promise of performance conditional on acceptance, but an undertaking against revocation, effective at any rate upon the dispatch of the letter of acceptance.

On principle, in the absence of some indication in the offer about a time limit for lapse, the offer should be irrevocable only until the lapse of

2 Dick v. United States, 82 F. Supp. 326 (Ct. Cl., r949). See 3 Corbin, Contracts $\S 609$ n. 47 (I95), justifying the result on the grounds of the offeree's mistake in his acceptance and the substitution of a new contract.

3 See for example the notes in 44 Ill. L. Rev. 394, 397 (I949); 62 Harv. L. Rev. I23I, 1232 (I949); 59 Yale L.J. 374, 376, 378 (I950); 25 Ind. L.J. 202 (I95); I7 Univ. Chi. L. Rev. 375, 378 (I950).

4 Acceptance and Rejection in Contracts by Correspondence, I 7 Univ. Chi. L. Rev. 375 (r950).

5 See, e.g., The Parol Evidence Rule: A Conservative View, p. 348 infra. 
a reasonable time for receipt of a reply. By a curious aberration, which must not distract us from the main theme of our discussion, the common law, and some European codes as well have put the entire risk of delay or loss on the offeror. Where the offeree has acted in reliance on the offer, and his "acceptance" has been lost or unreasonably delayed in the mails, as in a great range of comparable cases, the business-like solution of restitution with division of reliance losses seems more consistent with our working ideas of responsibility and property. ${ }^{6}$

For the present, that is not our main concern. We are concerned with a recognition, by trade opinion or by law, that an offer should under some circumstances, by reason of a term implied in fact, be irrevocable for some specified period whether or not beginning with the time when the offer is received and thus becomes a communication. The judgment expressed here depends in the end on that great complex of evaluations, psychological, moral, commercial, political, ideological, which is both a cause and an effect of the importance of the business undertaking in our society and our civilization. We are dealing next with the argument that it is unfair or somehow contrary to principle, or inconsistent with the nature of things, to treat an undertaking against revocation as binding in morals, commercial judgment or law, in the absence of acceptance by the offeree.

The second point, once it is stated, hardly needs to be refuted. It is, at least in its simple form, an outbreak of an uncritical notion of equality of a sort which at times for a while confuses the law. Another famous example affecting contract law was Lord Justice Fry's doctrine of "mutuality" as a limit on specific performance.

Equality is one of the two or three indispensable working notions of the law. For that very reason, it requires careful use. It does not require that people be treated identically, if there is a practical reason, of a sort with which courts are qualified to deal, for distinguishing them. The difference between an offeror who has made a promise to keep his offer open and an offeree who has made no promise at all hardly needs to be labored. The contractor to whom a bid is submitted, if by its terms it imports an undertaking against revocation, may reasonably depend both in his thinking and in his bidding on the assurance which is the mark of an undertaking. There would be no violation of any simple working idea of equality, if the bidder who has made a promise were treated quite differently from the contractor who has made none.

${ }^{6}$ See Loss Splitting in Contract Litigation, I8 Univ. Chi. I. Rev. I53 (I950).

7 See Limitations on the Availability of Specific Performance, $x_{7}$ Univ. Chi. L. Rev. 409 . $45^{-I 7}$, 4I9 (1950). 
So in the specified situation presented by the contract by correspondence, it is not surprising to find that the law has bound the offeror, for a time at least, on the dispatch of the offeree's letter of acceptance. The letter of acceptance lying in the mail box cannot however by any stretch of language be regarded as a promise. A promise, as the word is used by laymen and lawyers alike, imports some assurance to the promisee. A letter in a mail box cannot possibly give any such assurance. The offeror is bound, and some have jumped to the conclusion that this can be so only if the offeree is also bound. As the cases have begun to present clearly the problem of the offeree's obligation, it has seemed to the courts, as the writer understands them, that there was no justification for holding the offeree simply because his letter has been mailed. His letter in the course of transmission can have given no assurance to the offeror, and can have made no difference to him either psychologically or commercially. If after the dispatch of the letter of acceptance the offeree wires "disregard my letter; I reject," it cannot cause the offeror any significant disappointment or inconvenience to give effect to the communicated rejection, if he has not then received the letter containing the notations of acceptance. If the offeree retains the privilege of rejection by a communication anticipating the arrival of his letter of acceptance, basic notions of equality do not in turn require that the offeror's obligation not to revoke should be reexamined.

II

It may be that a somewhat less fundamental notion is a justification or explanation of the strong feeling which expresses itself in Mr. Llewellyn's remarks on the contract by correspondence, in some of the law review notes on the recent decision of the Court of Claims, and in Mr. Schultz's conclusions about the obligations of bidders. There appears to be a feeling that undertakings for which no return is made ought not to be enforced.

Both the continental European law and the English law enlarged very cautiously the classification of promises enforceable in court. In the Roman and continental law, the limitations on the enforcement of promises which may be explained as dependent on the feeling for "exchange" have been almost entirely superseded. The controlling principle of the continental European law is that deliberate words of promise should be enforced according to their terms; subject to precautions designed primarily to assure deliberation and to give effect to familiar policies about duress, fraud, mistake, changing conditions, and the relationships between contract and other bases of liability. The doctrines of consideration, 
which are partly a vestigial result of the evolution and crystallization of ideas, and partly a result of the peculiar history of the jurisdiction of the common-law courts, may be developing in the same direction.

The notion of harm that plays so important a part in the evolution of the action of assumpsit has appeared again as a source of growth in the developing doctrine that promises will be enforced, whether by the allowance of reliance damages or by the allowance of expectation damages, where the promise has occasioned reasonable reliance in the conduct of the promisee's affairs. The evolution of this notion received its most striking check under the influence of a countervailing notion that promises should not be enforced unless some price had been paid for them in exchange. This countervailing notion was announced by Chancellor Kent and strengthened by Langdell, though-unlike Kent-Langdell recognized its unhistorical character. Certainly everything that Mr. Llewellyn or Mr. Schultz says or implies about the notion of exchange should be taken subject to the limitation that a promise should be enforced, at least to the extent of reliance damages, if it has occasioned reasonable reliance in conduct as distinct from simple psychological reliance ${ }^{8}$

This notion of exchange, of that reciprocity which Malinowski has studied at work among the Trobriand Islanders, ${ }^{9}$ is itself capable of expanding the classification of enforceable promises. Thus promises in return for past benefits are on the way to develop a more general principle than any which the common law has as yet recognized. ${ }^{0}$ To say that some element of benefit to the promisor is necessary for the enforcement of his promise is, however, quite different.

Promises to make gifts may for a variety of reasons, some of them connected with our notions of property, require special safeguards of form. It seems to the writer, moreover, that there is much more sense than it is fashionable to recognize in the doctrines of the common law making promises ineffectual when they are given in exchange for less than the amount of an admittedly due debt, or when they are made to gain the performance of an admitted obligation, or when they occur by way of pretended compromise of merely specious claims or defenses. Here ques-

${ }^{8}$ See the author's Pacta Sunt Servanda, 4I Col. L. Rev. 783, 79I (I94I).

9 See Malinowski, Crime and Custom in Savage Society, I7-32 (I926); and compare Llewellyn and Hoebel, The Cheyenne Way, 266-67 (r94I).

10 As to sureties' undertakings, see Sharp, op. cit. supra note 8, at 794; Hays, Consideration: A Legislative Program, 4I Col. L. Rev. 849, 858-59 (I94I). Cf. Webb v. McGowin, 27 Ala. App. 82, I68 So. I96 (I935), cert. denied, 232 Ala. 374, I68 So. I99 (1936). For an interesting interaction between notions of past consideration and "value," consider Elgin Nat"l Bank v. Goecke, 295 Ill. 403, 129 N.E. 149 (1920). 
tions of duress as well as exchange are present and a modern form seems needed for protection. ${ }^{\text {.x }}$

When an offer, for example one which falls just short of turning into a requirement contract, may be read as containing by implication an undertaking that it will be kept open for a long time, for example, a year, the author confesses that a feeling probably involving reciprocity leads him to the conclusion that it should not be enforced according to its terms. Here an element of sense in the feeling of reciprocity as a limiting factor seems to appear. If however a modern form were used, such as the words "I intend to be legally bound not to revoke this offer for one year," the author would find that his sense of fairness was adequately served and that the undertaking should be enforceable according to its terms. It may be therefore that those other functions of form and consideration are what affect the author's judgment. These are the functions of marking off the promise, requiring somewhat elaborate proofs, and assuring deliberation on the part of the promisor.

The different set of notions, that reciprocity should be observed, that there should be some minimum fairness of exchange, that some premium should be required for taking risks or underwriting uncertainties, these notions have indeed vitality. They may reflect subtle psychological impulses and insights: the impulse to limit severity, the impulse to think in traders' patterns, the impulse to respect-as magic entities-any patterns once created in the law.

These notions must however be carefully guarded if they are not to mislead us in dealing with the rather limited problem of contracts by correspondence and the somewhat larger problem of offers which "expressly" or by the reasonable implication of words read in context, contain undertakings against revocation.

\section{III}

Each of the three cases which have raised in most interesting form the questions which have thus far been discussed is complicated by the presence of mistake: In one case the offeror whose bid had been acted on discovered a mistake in his figures, and then revoked his offer. ${ }^{12}$ In the second case, a situation of the same sort was supposed as the basis for a wellconsidered dictum, qualified immediately by a questionable counter-

\footnotetext{
Ix Compare, for example, I Page, Contracts $\$ \S 593-94$ (2d ed., IgIg) (containing a careful statement of the authorities) with I Corbin, Contracts $\$ \S x 76-83$ (1950); and consider the characteristic facts in Havana Press Drill Co. v. Ashurst, I48 Ill. II 5 (I894).

12 James Baird Co. v. Gimbel Bros., Inc., 64 F. 2d 344 (C.A. 2d, I933).
} 
dictum. ${ }^{13}$ In the third case, a case of alleged contract by correspondence, the offeree who anticipated the arrival of his letter of acceptance by a communicated rejection did so because of a mistake in his acceptance..$^{14}$ It is arguable that the element of mistake influenced the results in the first and third cases. Each however rests on a statement of principle which would apply as well if the attempted revocation in one case or rejection in the other had been based on changes in market prices.

The author is favorable to relief for mistake, and particularly to relief for the "unilateral" mistake appearing in each of the cases, subject to suitable equitable safeguards. ${ }^{15} \mathrm{He}$ would not support the decision in the first case on this ground, because of the change of position resulting from the sequence of bids in that case. He would if necessary reach the result in the third case on grounds of mistake. He cannot support the counterdictum in the second case in its application of mistake doctrine. It seems to him that the court gave too little effect to the circumstance that the recipient of the first offer had in turn submitted an offer himself, which had been accepted, and which, in spite of some evidence to the contrary, he might have had more or less difficulty, commercial or legal, in withdrawing. It is interesting to consider the mistake problems suggested by these three cases, but they do not seem to eliminate the opinions and decisions as authorities on the other points which have been discussed.

Professor Schultz may however be interested at some point in examining the opinions of contractors about the problem of so-called unilateral mistake which has produced more litigation than any other. This is the problem of mistake, whether clerical or arithmetical, in computing figures used in bidding. While it is arguable that a contractor should be treated as "warranting" the accuracy of his figures in dealing with nonprofessionals, there is a difference of opinion on this matter. On the other hand, in dealing with professionals, the contractor's error is very likely to be "palpable" in that an alert professional should have noticed it, or must be treated as though he had noticed it, and relief will often be granted on this ground.

When action has been taken on the faith of bids, a corrective principle based on change of position may appear, and relief may be denied. It would be more consistent with the somewhat analogous principles of tort liability to hold the mistaken contractor liable for reliance damages, for

${ }^{23}$ Robert Gordon, Inc. v. Ingersoll-Rand Co., II7 F. 2d 654, 660-6r (C.A. 7th, 194I).

${ }^{4}$ Dick v. United States, 82 F. Supp. 326 (Ct. Cl., I949).

rs See 3 Corbin, Contracts $\$ \S 598,608-609$ (r950) for relevant parts of an excellent discussion of mistake. 
example the difference between the next lowest bid, if it has been lost, and the price which the owner eventually has to pay; and relieve him from expectation damages, the benefit of the bargain, the difference between his mistaken bid and what the owner has to pay.

Deliberate chance-taking is arguably the only appropriate basis for the expectation damages so familiar to the lawyer, the damages designed to give the obligee the benefit of his bargain. The deliberate and unmistaken promise, with all the range of gambles which it may deliberately underwrite, is the one which is most likely to work out well, humanly and commercially. Its benefit must be assured in any chance-taking economy, indeed in some form in any economy which we can imagine. The mistaken promise, made with or without negligence, like a negligent tort, needs only to give rise at most to a charge against the promisor to cover any resulting loss leaving the promisee worse off than he was before the promise.

Whether or not these distinctions, derived partly from the civil law, may be worked into the patterns of the common law, it appears to the writer that a reasonable use of mistake doctrine would lead us to the solution of a good many problems which may otherwise be solved in ways which may unnecessarily confuse the law. If the security of expectations is likely to be promoted, as the author thinks, by an increasing caution in the use of doctrines of acceptance, mutuality and consideration, it seems equally likely that the security of transactions will be somewhat less regarded, as time goes on, in situations where there is unilateral mistake of a character which would afford a basis for relief if it were mutual.

Judge Frank's opinion in Ricketts v. Pennsylvania $R$. Co ${ }^{16}$ approves a decision relieving a dining car waiter from a personal injury release on the grounds, first, that the release resulted from a unilateral mistake about its contents, and second, it seems, on the ground that the waiter in giving the release was a victim of "economic inequality." Judge Frank was kind enough to cite the author in support of his conclusion, and the author is indeed in complete agreement with what Judge Frank says on the first point and on "objective theory" in general. It seems likely that the elements of good sense in traditional objective theory are being carefully limited, with healthy results, by what may perhaps be appropriately called an emerging "subjective theory."

Such a subjective theory may save us from trying to develop Judge Frank's second point into a systematic theory of inequality of bargaining ${ }^{16}{ }_{153}$ F. $2 \mathrm{~d} 757$ (C.A. 7 th, $x 946$ ). 
power. ${ }^{17}$ The concern for the subcontractor as the "weaker party" expressed by Mr. Schultz depends of course on a theory of "inequality" in this third sense.

"Inequality of bargaining power" is likely to mean differences in wealth or income. In a society based on differential returns, furnishing incentives and means of self-expression, it is hard to see how differences in wealth or income can be systematically developed as bases for judicial decisions. ${ }^{18}$ Another meaning of inequality of bargaining power, intelligible in theory, depends on the existence of "monopoly" or "monopsony" in the sense in which such phenomena need to be proved for convictions under the Sherman Act. While such a use of the terms is intelligible in theory, it might in practice introduce into private litigation all of the elaborate difficulties which appear in prolonged government prosecutions under the antitrust laws.

It is of course in the field of insurance that rough practical notions of the inequality of bargaining power have had their most striking effect. So conservative a writer as $\mathrm{Mr}$. Williston has suggested ${ }^{\mathrm{r} 9}$ that some of the most startling results in the insurance cases can be explained as well by principles governing relief for mistake as by the questionable notions about bargaining power which appear so prominently in discussions of insurance and which seem indeed to have influenced the courts in arriving at decisions. As the export shipper or ship owner was followed by the ordinary man getting his life insured, confusion of mind on the part of those getting insurance appears to have increased in a way quite as significant as the increasing spread between the resources of the insured and the resources of the insurance companies, not infrequently mutual companies in the billion-dollar asset class. It may seem a small point, but it seems to the writer worth-while to concentrate some attention on the confusions rather than on differences in resources. We need in dealing with such situations to recall the paradox in our social scheme, which values equality but which insists also on freedom and differential returns. Relief for mistake is consistent with the assumptions of such a system; but relief on ac(I950).

${ }_{77}$ Cf. Policing Contracts Under the Proposed Commercial Code, I8 Univ. Chi. L. Rev. 146

${ }^{28}$ The difficulty is there even though a fairly good individualist like Bentham suggested, in his Principles of the Civil Code, that some of the losses resulting from breach of contract should be distributed "among the parties interested, in proportion to their property." I Works of Jeremy Bentham (Bowring ed., 1843).

${ }^{29} 3$ Contracts $\$ \S 749-50$ (rev. ed., r936); cf. ibid., $\$ \S 759-60$. 
count of any disparity in resources permitted by the legislature seems inconsistent with such a system.

The cases which we have used as a basis for discussing some of the problems raised by Professor Schultz's study, serve at once to remind us that the security of undertakings is limited by a number of corrective principles, including principles governing relief for mistake, and to indicate that along with the refinement of these principles another refinement is taking place tending to enlarge the protection given to the security of expectations. In the development of current and counter-current, increasing knowledge of both the practices and the judgments of businessmen will contribute its part. The judgments must be both welcomed and criticized, and they seem likely to be of considerable help in the work of the profession. Toward the development of our understanding of business practices and judgments, Mr. Schultz has made a notable contribution. 